\title{
Loop-mediated isothermal amplification assay for the detection of Ehrlichia canis DNA in blood samples from dogs"
}

\author{
Ensayo de amplificación isotérmica de ADN mediada por asas para la detección del ADN \\ de Ehrlichia canis en muestras de sangre de perros
}

\author{
SA Faggion, AR Salvador, KL Jacobino, LFB Bortolotto, MB Lopes, M Silva, EV Santos, \\ AL Fachin, SC França, M Marins"
}

Unidade de Biotecnologia, Universidade de Ribeirão Preto, Brazil.

\begin{abstract}
RESUMEN
La bacteria rickettsia Ehrlichia canis es el agente etiológico de la ehrlichiosis monocítica canina, una de las más importantes enfermedades caninas transmitidas por garrapatas. En este estudio, un ensayo de amplificación isotérmica de ADN mediada por asas (LAMP) se desarrolló para la detección del ADN de E. canis usando iniciadores LAMP enfocando el operón groESL. Se produjeron reacciones a $60^{\circ} \mathrm{C}$ por $60 \mathrm{~min}$ y los resultados se visualizaron por electroforesis en gel. Se obtuvo una exitosa amplificación al usar ADN plasmídico conteniendo un fragmento del operón groESL y ADN extraído de muestras de sangre que dieron positivo para E. canis vía PCR en tiempo real. La especificidad de amplificación fue confirmada por la enzima de restricción EcoRI de sitios internos en iniciadores LAMP y no se observó ninguna reactividad cruzada con muestras de sangre positivas para Babesia spp., otro agente patógeno común transmitido por garrapatas. El alto costo de análisis de ácido nucleico es uno de los inconvenientes para su uso a gran escala como pruebas diagnósticas rutinarias. El ensayo LAMP para E. canis desarrollado aquí es una alternativa interesante para PCR, una vez que no requiere un termociclador programado y, consecuentemente, reduce costos para el laboratorio clínico veterinario.
\end{abstract}

Palabras clave: Ehrlichiosis monocítica canina, Ehrlichia canis, LAMP

\section{SUMMARY}

The rickettsial bacterium Ehrlichia canis is the etiological agent of canine monocytic ehrlichiosis, one of the most important canine tick-borne diseases in the world. In this study, a loop-mediated isothermal amplification (LAMP) assay was developed for detection of $E$. canis DNA using LAMP primers targeting the groESL operon. Reactions were performed at $60^{\circ} \mathrm{C}$ for $60 \mathrm{~min}$ and the results were visualized by gel electrophoresis. Successful amplification was obtained using plasmid DNA containing a fragment of the groESL operon and DNA extracted from blood samples that tested positive for E. canis by real-time PCR. The specificity of amplification was confirmed by EcoRI restriction of internal sites in the LAMP primers and no crossreactivity with blood samples positive for Babesia spp., another common tick-borne pathogen, was observed. The high cost of nucleic acid tests (NAT) is one of the disadvantages for their large-scale use as routine diagnostic tests. The E. canis LAMP assay developed here is an interesting alternative to PCR since it does not require a thermocycler, thus reducing costs for the veterinary clinical laboratory.

Key words: canine monocytic ehrlichiosis, Ehrlichia canis, LAMP.

\section{INTRODUCTION}

The pet dog population has increased tremendously in the world and parasitic diseases are a major health concern. In tropical countries, the infection of dogs with Ehrlichia canis is one of the most common diseases in veterinary practice, probably because the vector tick Rhipicephalus sanguineus is common in rural and urban

Accepted: 28.12.2012.

\# Fundação de Amparo à Pesquisa do Estado de São Paulo (grants 09/17017-8 and 10/15769-0), CAPES and MEC through fellowships granted to E.V.S., L.F.B, K.L.J.and M.S.

* Unidade de Biotecnologia - UNAERP, Av. Costábile Romano, 2201, Ribeirão Preto, SP, CEP 14096-900, Brazil; marins@ heranza. com.br. areas (Aguiar et al 2007, Dantas-Torres 2008'). Dogs may develop canine monocytic ehrlichiosis (CME) 8 - 20 days after infection. The disease can appear in its acute, subclinical, or chronic form (Harrus and Waner 2011, Skotarczak 2003, Vieira et al 2011). In the acute form, dogs present fever, depression, lethargy, anorexia, lymphadenomegaly, splenomegaly, mucosal pallor, conjunctivitis, and ocular discharge. Thrombocytopenia and leukopenia are common laboratory findings of this phase. After the acute phase, dogs may enter the subclinical phase that is characterised by the absence of evident clinical signs other than mild thrombocytopenia, which can last 40 120 days to years. A matter of concern is the progression of CME to the chronic form, which is characterised by the presence of physical and hematological signs similar to those seen during the acute phase. 
CME is a multisystemic disease with clinical signs overlapping other infections, theerfore its diagnosis can be improved by using specific diagnostic tests combined with physical and hematological evaluation (de et al 2011, Harrus and Waner 2011, Nakaghi et al 2010). Blood smears for the detection of morulae, serology, cell culture, and PCR are common tests used. The search for morulae may allow a reasonable sensitivity of detection during the acute phase of infection but not during the other phases of the disease (Harrus and Waner 2011, Woody and Hoskins 1991). Serological tests are criticized since they may produce false-positive results due to cross-reactions with other species or with antibodies from previous infections whose titers can remain high for long periods of time even after treatment (Harrus et al 1998). Moreover, falsenegative results are observed during the acute phase of infection due to low antibody titers (Nakaghi et al 2008). Currently, NAT such as PCR, nested PCR and real-time PCR are considered to be the most sensitive and specific tests for the detection of E. canis and other hemoparasites (Harrus and Waner 2011, Nakaghi et al 2010), but their routine use in veterinary practice is difficult due to their high cost and because these tests are time consuming.

Loop-mediated isothermal amplification (LAMP) is a low-cost and rapid isothermal DNA amplification technique since it does not require the use of a thermocycler and the results can be directly visualized in the test tubes (Mori and Notomi 2009, Notomi et al 2000). In classical PCR, specificity is limited to the recognition of two regions in the target DNA, to four regions in nested PCR, and to three in TaqMan probe-based real-time assays. In LAMP assays, specificity is increased by the use of two sense and two reverse primers, called FIP, F3, BIP and B3, which recognize six regions in the target DNA. This technique has been successfully applied to the detection of different pathogens, including the rickettsial agents Ehrlichia ruminantium and Anaplasma ovis (Ma et al 2011, Nakao et al 2010). In this study, a LAMP assay was developed for the detection of E. canis while its sensitivity and specificity were evaluated using plasmid standards and genomic DNA extracted from blood samples of dogs with clinical signs of CME that tested positive for $E$. canis DNA by real-time PCR.

\section{MATERIAL AND METHODS}

\section{CLINICAL SAMPLES AND DNA EXTRACTION}

EDTA-anticoagulated blood samples from four dogs with a clinical suspicion of ehrlichiosis, which tested positive for $E$. canis DNA by real-time PCR, were used for the LAMP assays. One dog negative for E. canis DNA and one dog positive for Babesia canis DNA were used as negative and specificity controls, respectively. DNA was extracted from $200 \mu \mathrm{l}$ blood using the NucleoSpin Blood kit (Macherey-Nagel, Germany).

\section{REAL-TIME PCR}

The real-time TaqMan PCR assay was based on the detection of the E. canis heat shock operon groESL, with the primers and probe targeting a 175-bp region of the corresponding DNA sequence (bases 443 to 617, GenBank Accession No. U96731). The IX Master Mix (Roche Real-Time PCR Mix) was used for the reaction, with the final volume of $25 \mu \mathrm{l}$ containing $200 \mathrm{nM}$ of the forward primer ECGROTQFWD (5'-GCGAAAGTTATAGAAGAA-3') and of the reverse primer ECGROTQREV (5'-CACCATTAGCGGAAATAG-3') and $100 \mathrm{nM}$ of the ECGROPROBE probe (5'-FAM-TGAAACGTGAAATACTATCTGAAGA-BQH1-3'). PCR and fluorescence detection were performed using the Stratagene Mx3000P system (Stratagene, La Jolla, CA). The thermal cycler program was set at $95^{\circ} \mathrm{C}$ for $10 \mathrm{~min}$, followed by 40 cycles of $95^{\circ} \mathrm{C}$ for $15 \mathrm{~s}, 60^{\circ} \mathrm{C}$ for $20 \mathrm{~s}$, and $72^{\circ} \mathrm{C}$ for 20 s. The same procedure was used for the detection of $B$. canis in blood samples using BABF 5'-CACMGTVCAGGARGACAT-3' and BABR 5'-CRGCRATTTCCTTCATCT-3' as primers and BABPROBE 5'-CY5-CCATTCAAGGTCATCAACGGTG-BHQ1-3' as the probe. The primers and probe targeted a DNA region corresponding to the $B$. canis group heat shock protein 70 (bases 240 to 394, GenBank Accession No. AB248735).

\section{LAMP PRIMERS AND REACTION}

The LAMP specific primers for $E$. canis were designed to target the groESL operon of the parasite using a LAMP primer designing software (PrimerExplorer V4, Eiken Chemical Co., Japan) ${ }^{1}$. The 379-606 region of the GenBank sequence U96731 was used as a reference (table 1). Previously sequenced PCR fragments of the studied region obtained in our laboratory from blood samples of dogs and sequences deposited in GenBank, were aligned with the ClustalX program (Larkin et al 2007) in

Table 1. Nucleotide sequences of LAMP primers used for the detection of E. canis.

Secuencias de nucleótidos de los iniciadores de LAMP utilizados para la detección de E. canis.

\begin{tabular}{ll}
\hline Primer & Sequence $\left(5^{\prime}-3^{\prime}\right)^{\mathrm{a}}$ \\
\hline GROF3 & TCAGAGTGCTTCTCAGTGTA \\
GROB3 & GGAAATAGTAGCAACTTGAGC \\
GROFIP & CCAGCAGCTTTAGCTTTAGAAACT gaattC- \\
& GATAAAGTTGGTGATGGAAC \\
GROBIP & GGTGTACTTAAAGCTAAAGAGGCTGaat- \\
& $t C$ CTCAGATAATACCTCACGC \\
\hline
\end{tabular}

${ }^{a}$ Letters in italics in the FIP and BIP primer sequences indicate EcoRI restriction sites.

http://primerexplorer.jp/elamp4.0.0/index.html 
order to identify sequence conservation. An EcoRI restriction site was also created in the FIP and BIP primers for subsequent restriction analysis of the LAMP products (table 1). Each LAMP reaction mixture contained $1 \mu \mathrm{l}$ extracted DNA, $20 \mathrm{pmol}$ of each FIP and BIP primer, 5 pmol of each F3 and B3 primer, $0.5 \mathrm{mM}$ of each dNTP, and $1 \mathrm{X}$ ThermoPol reaction buffer $(20 \mathrm{mM}$ Tris- $\mathrm{HCl}, 10$ $\mathrm{mM} \mathrm{KCl}, 10 \mathrm{mM}\left(\mathrm{NH}_{4}\right)_{2} \mathrm{SO}_{4}, 2 \mathrm{mM} \mathrm{MgSO}{ }_{4}, 0.1 \%$ Triton $\mathrm{X}-100, \mathrm{pH} 8.8$ ). The final volume was adjusted to $19 \mu \mathrm{l}$ with autoclaved ultrapure water and the mixture was incubated at $95^{\circ} \mathrm{C}$ for $2 \mathrm{~min}$, followed by incubation in ice. After the addition of 8 units Bst DNA polymerase large fragment (New England Biolabs, UK), the reactions were incubated at $60^{\circ} \mathrm{C}$ for $60 \mathrm{~min}$ and subsequently at $80^{\circ} \mathrm{C}$ for $10 \mathrm{~min}$ to terminate the reaction. A $10 \mu \mathrm{l}$ aliquot of each reaction was used for electrophoresis on $2.5 \%$ agarose gel in Tris-acetic acid-EDTA (TAE) buffer and visualized under UV light after staining with ethidium bromide.

\section{DETECTION THRESHOLD AND SPECIFICITY OF THE LAMP ASSAY}

The sensitivity of the assay was evaluated using a cloned fragment of the groESL operon encompassing the region amplified by the LAMP reaction. Plasmid DNA concentrations were measured with the Genequant 1300 system (GE Healthcare, US) and the corresponding copy numbers were calculated. The plasmid was diluted to contain $10^{5}$ copies/ $\mu \mathrm{l}$ and 10 -fold serial dilutions were then prepared. One microliter was used in each reaction mixture to evaluate the detection threshold of the assay. The LAMP products were digested with EcoRI to confirm the cross-reactivity of the amplifications. Cross-reactivity was also evaluated using genomic DNA extracted from a blood sample positive for $B$. canis infection.

\section{RESULTS AND DISCUSSION}

In the present study, we successfully developed a LAMP assay for the detection of E. canis. This test was based on the amplification of a fragment of the groESL operon, which has been shown to be a useful target for development of PCR-based assays for the detection of different Anaplasmataceae species (Inokuma et al 2002, Sumner et al 1997, 2000). The sequence specificity and conservation of this region within species and among different strains are enough to guarantee reliable results for its application in epidemiological studies or as a diagnostic tool involving samples of different geographic origins (Sumner et al 1997). Initially, the LAMP reactions were performed at $55^{\circ}$ and $60^{\circ} \mathrm{C}$ using plasmid DNA ( $10^{5}$ copies per reaction) for 60 and $120 \mathrm{~min}$. The best results, indicated by the typical ladder pattern after electrophoresis on agarose gel, were obtained by incubation at $60^{\circ} \mathrm{C}$ for $60 \mathrm{~min}$. Using this parameters, the sensitivity of LAMP was determined by analyzing 10-fold serial dilutions of plasmid DNA (starting from $10^{4}$ copies) that contained the E. canis heat shock operon groESL. The LAMP assay had a detection limit of 1 copy of plasmid DNA (figure 1). The assay was then tested for the detection of $E$. canis DNA with clinical samples obtained from six dogs with a suspicion of ehrlichiosis seen at a private clinic in the city of Ribeirão Preto, Brazil. Real-time PCR confirmed the infection of four dogs with E. canis, one dog was infected with B. canis, and one dog was not infected with either of these parasites. The four samples that previously tested positive by Real-time PCR were also positive for $E$. canis DNA and the other two samples were negative (figure 2). This experiment also showed that no nonspecific amplification was observed for water samples used as negative controls, DNA from uninfected blood, and DNA from blood samples infected with $B$. canis. Correct amplification of the target sequence was also confirmed by comparison of undigested LAMP products and products digested with EcoRI and analyzed by agarose gel electrophoresis (figure 3). When combined with clinical findings and serological tests, Nucleic Acid Tests (NAT) are a valuable diagnostic tool for the detection and identification of parasites (Dumler and Valsamakis 1999). While classical PCR assays need specialized equipment, LAMP assays can be performed in a water bath, eliminating the need for a thermocycler, and optimized for visualization of results directly with a naked eye, dispensing the use of gel electrophoresis (Mori and Notomi 2009). There is a positive impact in the reduction of investments costs for a veterinary clinic when setting up NAT based diagnostics. Moreover, results can be ob-

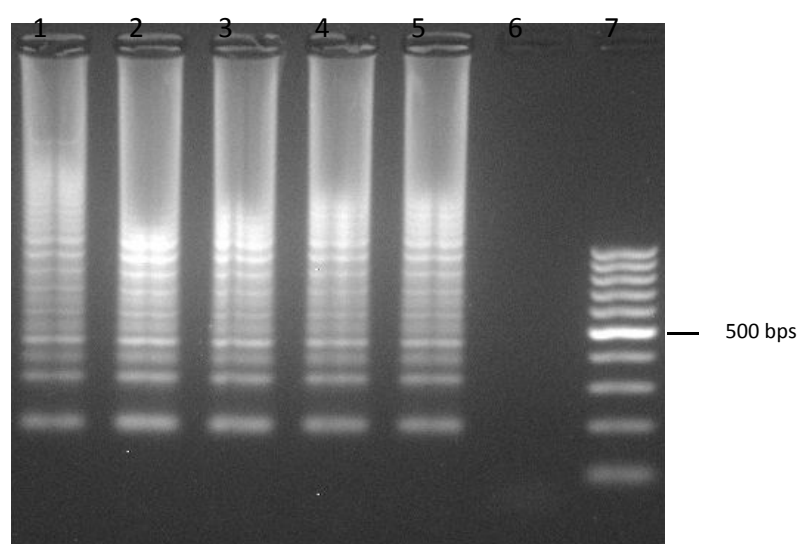

Figure 1. Representative electrophoretic agarose gel showing the result of LAMP assay for sensitivity using 10-fold serial dilutions of plasmid DNA containing the E. canis groESL operon. Lanes 1-5, from $10^{4}$ to 1 copies; Lane 6, negative water control; Lane 7, 100 bps DNA ladder (Fermentas).

Gel electroforético de agarosa representativo del resultado de ensayo de LAMP para la sensibilidad, usando 10-veces diluciones seriadas de ADN de plásmido que contiene el operón groESL de $E$. canis. Carriles 1-5, $10^{4}$ a 1 copias; carril 6, el control negativo de agua; carril 7, escalera de DNA de 100 pbs (Fermentas). 




Figure 2. Representative electrophoretic agarose gel showing the results of LAMP assay for detection of E. canis groESL operon. Lane 1, 100 bps DNA ladder (Fermentas); Lane 2-5, charachteristic LAMP ladder of positive $E$. canis samples; Lane 6, no LAMP product with a B. canis infected sample; Lane 7, negative water control; Lane 8, $1 \mathrm{~Kb}$ DNA ladder (Fermentas).

Gel electroforético de agarosa representativo de el resultado de ensayo de LAMP para la detección de E. canis groESL operon. Carril 1, escalera de DNA de 100 pbs (Fermentas); Carriles 2-5, escalera característica de la LAMP para pueblas positivas de E. canis; Carril 6, ningún producto de LAMP con una muestra infectada $\operatorname{com} B$. canis; Carril 7, control negativo de agua; Carril 8, escalera de DNA de $1 \mathrm{~Kb}$ (Fermentas).

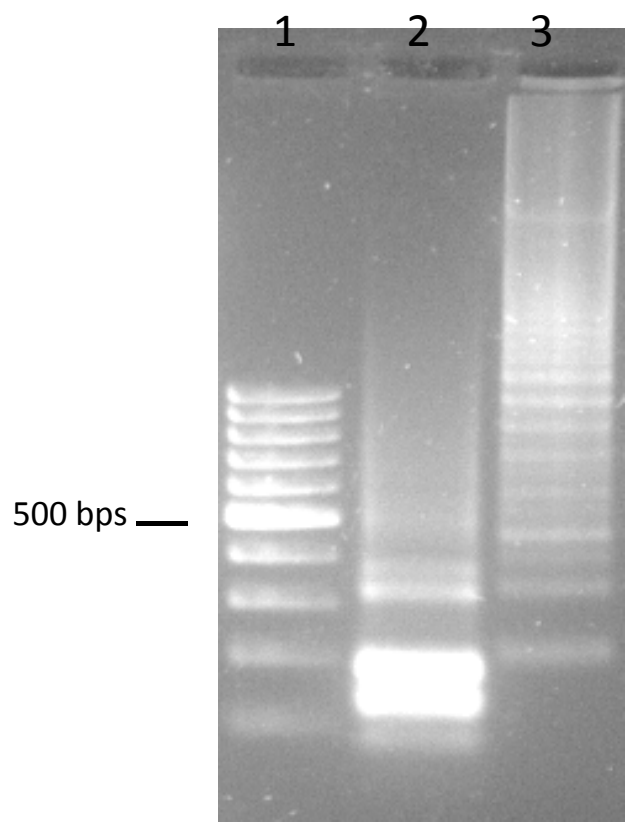

Figure 3. Representative electrophoretic agarose gel showing the result of restriction digestion of LAMP product with EcoRI. Lane 1, 100 bps DNA ladder (Fermentas); Lane 2, EcoRI digest of LAMP product from a $E$. canis positive sample; Lane 3, Undigested LAMP product from a $E$. canis positive sample.

Gel electroforético de agarosa representativo de el resultado de la restricción de el producto de LAMP com EcoRI. Carril 1, escalera de DNA de 100 pbs (Fermentas); Carril 2, restricción com EcoRI de el producto de LAMP de una puebla positiva de E. canis; Carril 3, producto de LAMP no digerido de una muestra positiva de E. canis. tained within $1 \mathrm{~h}$ and with further development, i.e. using additional loop primers, the reaction incubation period can be further reduced (Nagamine et al 2002). On the other hand, in order to avoid cross contamination by excessive manipulations of samples and reactions, it will be interesting to develop standard reaction mixtures where it would only be necessary to add the test sample. Nevertheless, the assay developed here specifically amplified E. canis DNA and did not result in nonspecific amplification in a negative sample or a sample infected with $B$. canis, in agreement with the results of the real-time PCR assay. The sensitivity of the assay, which was established using 10-fold serial dilutions of plasmid DNA containing a fragment of the groESL operon, was 1 copy of plasmid DNA. This sensitivity can be compared to that reported for other LAMP assays developed for Anaplasmataceae (Ma et al 2011, Nakao et al 2010) and other studies have demonstrated the higher sensitivity of the method when compared to PCR (Alhassan et al 2007, Cho et al 2006, Ma et al 2011, Matovu et al 2010).

In summary, the E. canis LAMP assay developed in this study is a rapid, straightforward and low-cost NAT that can be installed in veterinary laboratories. Once a larger scale study is conducted to validate it as a diagnostic test, it may improve the diagnosis of CME, a common disease in tropical countries that shows overlapping symptoms with other diseases that are endemic in these regions such as babesiosis and leishmaniosis (Dantas-Torres 2008 ${ }^{\text {b }}$.

\section{ACKNOWLEDGMENTS}

We would like to thank the staff of the Biotechnology Unit, UNAERP, for general support and K.M. for English revision.

\section{REFERENCES}

Aguiar DM, GT Cavalcante, A Pinter, SM Gennari, LM Camargo, MB Labruna. 2007. Prevalence of Ehrlichia canis (Rickettsiales: Anaplasmataceae) in dogs and Rhipicephalus sanguineus (Acari: Ixodidae) ticks from Brazil. J Med Entomol 44, 126-132.

Alhassan A, Y Govind, NT Tam, OM Thekisoe, N Yokoyama, $\mathrm{N}$ Inoue, I Igarashi. 2007. Comparative evaluation of the sensitivity of LAMP, PCR and in vitro culture methods for the diagnosis of equine piroplasmosis. Parasitol Res 100, 1165-1168.

Cho HS, JI Kang, NY Park. 2006. Detection of canine parvovirus in fecal samples using loop-mediated isothermal amplification. $J$ Vet Diagn Invest 18, 81-84.

Dantas-Torres F. 2008 ${ }^{\mathrm{a}}$. The brown dog tick, Rhipicephalus sanguineus (Latreille, 1806) (Acari: Ixodidae): from taxonomy to control. Vet Parasitol 152, 173-185.

Dantas-Torres F. 2008 ${ }^{\text {b }}$ Canine vector-borne diseases in Brazil. Parasit Vectors 1, 25.

de Caprariis D, F Dantas-Torres, G Capelli, N Mencke, D Stanneck, EB Breitschwerdt, D Otranto. 2011. Evolution of clinical, haematological and biochemical findings in young dogs naturally infected by vector-borne pathogens. 
Vet Microbiol 149, 206-212.

Dumler JS, A Valsamakis. 1999. Molecular diagnostics for existing and emerging infections. Complementary tools for a new era of clinical microbiology. Am J Clin Path 112, S33-39.

Harrus S, T Waner, I Aizenberg, JE Foley, AM Poland, H Bark. 1998. Amplification of ehrlichial DNA from dogs 34 months after infection with Ehrlichia canis. J Clin Microbiol 36, 73-76.

Harrus S, T Waner. 2011. Diagnosis of canine monocytotropic ehrlichiosis (Ehrlichia canis): an overview. Vet J 187, 292296.

Inokuma H, K Fujii, M Okuda, T Onishi, JP Beaufils, D Raoult, P Brouqui. 2002. Determination of the nucleotide sequences of heat shock operon groESL and the citrate synthase gene (gltA) of Anaplasma (Ehrlichia) platys for phylogenetic and diagnostic studies. Clin Diagn Lab Immunol 9, 1132-1136.

Larkin MA, G Blackshields, NP Brown, R Chenna, PA McGettigan, H McWilliam, F Valentin, IM Wallace, A Wilm, R Lopez, JD Thompson, TJ Gibson, DG Higgins. 2007. Clustal W and Clustal X version 2.0. Bioinformatics 23, 2947-2948.

Ma M, Z Liu, M Sun, J Yang, G Guan, Y Li, J Luo, H Yin. 2011. Development and evaluation of a loop-mediated isothermal amplification method for rapid detection of Anaplasma ovis. J Clin Microbiol 49, 2143-2146.

Matovu E, I Kuepfer, A Boobo, S Kibona, C Burri. 2010. Comparative detection of trypanosomal DNA by loop-mediated isothermal amplification and PCR from flinders technology associates cards spotted with patient blood. J Clin Microbiol 48, 2087-2090.

Mori Y, T Notomi. 2009. Loop-mediated isothermal amplification (LAMP): a rapid, accurate, and cost-effective diagnostic method for infectious diseases. J Infect Chemother $15,62-69$.
Nagamine K, T Hase, T Notomi. 2002. Accelerated reaction by loop-mediated isothermal amplification using loop primers. Mol Cell Probes 16, 223-229.

Nakaghi AC, RZ Machado, MT Costa, MR André, CD Baldani. 2008. Canine ehrlichiosis: clinical, hematological, serological and molecular aspects. Ciênc Rural 38, 766-770.

Nakaghi AC, RZ Machado, JA Ferro, MB Labruna, AL Chryssafidis, MR Andre, CD Baldani. 2010. Sensitivity evaluation of a single-step PCR assay using Ehrlichia canis p28 gene as a target and its application in diagnosis of canine ehrlichiosis. Brazil J Vet Parasitol 19, 75-79.

Nakao R, EY Stromdahl, JW Magona, B Faburay, B Namangala, I Malele, N Inoue, D Geysen, K Kajino, F Jongejan, C Sugimoto. 2010. Development of loop-mediated isothermal amplification (LAMP) assays for rapid detection of Ehrlichia ruminantium. BMC Microbiol 10, 296.

Notomi T, H Okayama, H Masubuchi, T Yonekawa, K Watanabe, N Amino, T Hase. 2000. Loop-mediated isothermal amplification of DNA. Nucleic Acids Res 28, E63.

Skotarczak B. 2003. Canine ehrlichiosis. Ann Agric Environ Med 10, 137-141.

Sumner JW, WL Nicholson, RF Massung. 1997. PCR amplification and comparison of nucleotide sequences from the groESL heat shock operon of Ehrlichia species. J Clin Microbiol 35, 2087-2092.

Sumner JW, GA Storch, RS Buller, AM Liddell, SL Stockham, Y Rikihisa, S Messenger, CD Paddock. 2000. PCR amplification and phylogenetic analysis of groESL operon sequences from Ehrlichia ewingii and Ehrlichia muris. J Clin Microbiol 38, 2746-2749.

Vieira RF, AW Biondo, AM Guimaraes, AP Dos Santos, RP Dos Santos, LH Dutra, PP Diniz, HA de Morais, JB Messick, MB Labruna, O Vidotto. 2011. Ehrlichiosis in Brazil. Brazil J Vet Parasitol 20, 1-12.

Woody BJ, JD Hoskins. 1991. Ehrlichial diseases of dogs. Vet Clin N Am-Small 21, 75-98. 
